\title{
3-O-Acetyl-narcissidine, a Bioactive Alkaloid from Hippeastrum puniceum Lam. (Amaryllidaceae)
}

\author{
Omar Santana ${ }^{\mathrm{a}, \mathrm{e}}$, Matías Reina ${ }^{\mathrm{b}}$, Ana Luisa Anaya ${ }^{\mathrm{c}}$, Fidel Hernández ${ }^{\mathrm{d}}$, \\ M. Elena Izquierdo ${ }^{\mathrm{a}}$, and Azucena González-Coloma ${ }^{\mathrm{a}, *}$ \\ a Instituto de Ciencias Agrarias, CSIC, Serrano 115-dpdo, 28006 Madrid, Spain. \\ Fax: (+34) 91-5640800. E-mail: azu@ccma.csic.es \\ b Instituto de Productos Naturales y Agrobiología, CSIC, Avda. Astrofísico F. Sánchez 3, \\ 38206 La Laguna, Tenerife, Spain \\ c Instituto de Ecología, Universidad Nacional Autónoma de México, Tercer Circuito \\ Universitario, Ciudad Universitaria, 04510, Mexico DF \\ d Estación de Investigaciones de la Caña de Azúcar, INICA, Carretera Central km 156, \\ 42600 Jovellanos, Cuba \\ e Current address: Centro de Investigación Agraria, Banco de Germoplasma Vegetal \\ de Cuenca, Crta. Toledo-Cuenca, km 174, 16194 Cuenca, Spain \\ * Author for correspondence and reprint requests \\ Z. Naturforsch. 63c, 639-643 (2008); received March 10/April 24, 2008
}

In the context of the study on plant defensive compounds we have isolated the main alkaloid from Hippeastrum puniceum (Amaryllidaceae), 3-O-acetyl-narcissidine (1), and its biological activities tested against two divergent insect species and several plant species. 1 was isolated from the bioactive alkaloidal fraction of $H$. puniceum. Its chemical structure was established by spectroscopic analysis. The biological activity tests showed that $\mathbf{1}$ is an antifeedant against the polyphagous insect Spodoptera littoralis but not against the olyphage Leptinotarsa decemlineata. Furthermore, the root growth of Amaranthus hypochondriacus, Rottboellia cochinchinensis, Panicum maximum and Solanum lycopersicum was significantly affected by $\mathbf{1}$. These results suggest a plant protective role for $\mathrm{H}$. puniceum alkaloids.

Key words: Hippeastrum, Antifeedant, 3-O-Acetyl-narcissidine

\section{Introduction}

The Amaryllidaceae family is one of the most important alkaloid-containing plant families (Jin, 2005). Amaryllidaceae alkaloids have structural similarities to the essential amino acid phenylalanine and related metabolites of tyrosine (Fennell and van Staden, 2001). About 500 alkaloids have been described from this plant family with a wide range of pharmacological effects (Jin, 2005, 2007; Unver, 2007). Galanthamine is the most important and a long-acting, selective, reversible and competitive acetylcholinesterase (AChE) inhibitor (Heinrich and Teoh, 2004). Lycorine, another widely distributed alkaloid of this family, has been proven to have important biological activities including antiviral, antitumour, antimalarial, cytotoxic and anti-inflammatory activities (Weniger et al., 1995; Citoglu et al., 1998; Sener et al., 2003; Liu et al., 2004; Szlávik et al., 2004). Several other wellknown alkaloids of the Amaryllidaceae family, such as pancratistatin and narciclasine, have also been shown to possess promising antitumour activity (Pettit et al., 1986; Polt, 1996).
In this work, we isolated the major alkaloid, 3-O-acetyl-narcissidine (1), from Hippeastrum puniceum Lam. (Amaryllidaceae), a herbaceous plant with a globose or ovoid bulb, native to Central America, the West Indies, and the northern half of South America where it is widely cultivated (Meerow, 1990) and has been described as a remedy against swelling and sores (Asprey and Thornton, 1955; Mitchell and Ahmad, 2006). We also tested the activity of the plant extracts (ethanolic and alkaloidal) and $\mathbf{1}$ against two insect pests, the polyphagous Spodoptera littoralis Boisd. (Lepidoptera: Noctuidae) and the olyphagous Leptinotarsa decemlineata Say (Coleoptera: Chrysomelidae). Additionally their phytotoxic effects were evaluated against several weeds and a crop plant (Amaranthus hypochondriacus, Rottboellia cochinchinensis, Echinochloa crus-galli, Panicum maximum and Solanum lycopersicum). 


\section{Materials and Methods}

\section{General experimental procedures}

Optical rotations were determined at room temperature using a Perkin-Elmer 241 polarimeter. NMR spectra were measured on a Bruker AMX500 spectrometer with pulsed field gradient, using the solvent as an internal standard $\left(\mathrm{CDCl}_{3}\right.$, at $\delta_{\mathrm{H}}$ 7.26 and $\left.\delta_{\mathrm{C}} 77.0\right)$. Exact mass spectra and EI-mass spectra were recorded on an Autospect instrument at $70 \mathrm{eV}$. Silica gel from Merck (15111 and 5554) was used for column chromatography and preparative TLC. Silica gel G 1500/LS $254(200 \times$ $200 \times 0.25$ mm, Schleicher \& Schuell, Ref. 391132) were use for semipreparative TLC. Alkaloids were visualized on TLC plates with Dragendorff's reagent.

\section{Plant material}

Hippeastrum puniceum Lam. (Amaryllidaceae) was collected at the perimeter of the National Botanical Garden, La Habana, Cuba in the summer of 1997. Once collected, the plant material was dried at room temperature (5 d) and subsequently ground. A voucher specimen has been deposited at the Instituto de Ecología y Sistemática (IES), La Habana, Cuba.

\section{Extraction and isolation}

Dried plant material $(2.19 \mathrm{~kg})$ was thoroughly extracted with EtOH in a Soxhlet apparatus. The ethanolic extract (102 g, 4.65\% yield) was chromatographed using a silica gel vacuum-liquid chromatography column and hexane/EtOAc/MeOH gradients producing fractions 1-7. An alkaloidal extract $(1.47 \mathrm{~g}, 1.44 \%$ yield) was obtained from fraction 6 (EtOAc/MeOH, 50:50) as described by Domínguez et al. (2008), and then purified by CC and semipreparative TLC producing alkaloid $\mathbf{1}$ $(0.028 \mathrm{~g}, 0.027 \%$ yield $)$.

3-O-Acetyl-narcissidine (1) $\left(\mathrm{C}_{20} \mathrm{H}_{25} \mathrm{NO}_{6}\right):[\alpha]_{\mathrm{D}}$ $-46^{\circ}(c, 0.5) .-{ }^{1} \mathrm{H}$ NMR and ${ }^{13} \mathrm{C}$ NMR: see Quirion et al. (1991). - EIMS: $m / z=375[\mathrm{M}]^{+}, 374$ (8), 314 (19), 315 (59), 301 (7), 298 (10), 285 (31), 284 (100), 266 (56), 228 (20), 162 (9). - HREIMS: $m / z=375.1660$ (calcd. for $\mathrm{C}_{20} \mathrm{H}_{25} \mathrm{NO}_{6}$ ).

\section{Insect bioassays}

S. littoralis and L. decemlineata from a laboratory colony were reared on artificial diet (Poitout and Bues, 1970) and host plant foliage (Solanum tuberosum L. cv. Desirée), respectively, and maintained at $(22 \pm 1){ }^{\circ} \mathrm{C}, 60-70 \%$ relative humidity with a photoperiod of $16 \mathrm{~h}: 8 \mathrm{~h}$ (L:D) in a growth chamber.

Choice feeding assays were conducted with S. littoralis L6 larvae and adult L. decemlineata. The initial doses were $100 \mu \mathrm{g} / \mathrm{cm}^{2}$ for crude extracts and $50 \mu \mathrm{g} / \mathrm{cm}^{2}$ for the isolated compound. Percent feeding inhibition (\%FI) was calculated as described by Reina et al. (2001). Compounds with an $\mathrm{FI}>70 \%$ were tested in a dose-response experiment to calculate their relative potency $\left(\mathrm{EC}_{50}\right.$ values, the effective dose for $50 \%$ feeding reduction), which was determined from linear regression analysis (\%FI on log dose).

Oral cannulation. Pre-weighed newly molted S. littoralis L6 larvae as described by Reina et al. (2001) were orally injected with DMSO solutions of the test compound $(20 \mu \mathrm{g} /$ insect $)$.

Hemolymph injection. 20 adult L. decemlineata beetles as described by Reina et al. (2001) were abdominally injected with DMSO solutions of the test compounds $(10 \mu \mathrm{g} /$ insect $)$.

\section{Mutagenic assays}

The mutagenic activity tests were conducted with Salmonella typhimurium (Ames test) in the presence or absence of an active metabolic system as previously described (González-Coloma et al., 1998).

\section{Phytotoxic evaluation}

Seed of Amaranthus hypochondriacus L., Echinochloa crus-galli (L.) P. Beauv., Panicum maximum Jacq. and Rottboellia cochinchinensis (Lour.) W. D. Clayton were collected from their natural habitats. Solanum lycopersicum L. seeds were collected from cultivated plants in experimental gardens. Extract and alkaloid solutions (concentrations of 100 and $50 \mu \mathrm{g} / \mathrm{ml}$ in $\mathrm{MeOH}$ of extracts and pure compound, respectively) were prepared. Filter paper was impregnated with $1.5 \mathrm{ml}$ of the test solutions (treatment) or solvent alone (control) and placed in Petri dishes ( $5 \mathrm{~cm}$ diameter). Once the solvent had evaporated, the filter paper (treatment and control) was moistened with distilled water and 10 seeds were placed on each plate. Each experiment was repeated 4 times. After $72 \mathrm{~h}$ in a growth chamber $\left(27^{\circ} \mathrm{C}\right)$ the percentage of germination, root length (Anaya et al., 2003) and 
abnormal root growth were measured. The data was analyzed by simple ANOVA $(p<0.05)$.

\section{Results and Discussion}

Compound 1 was identified by comparing our results with those previously reported (Quirion et $a l ., 1991)$. This compound was previously isolated from $H$. puniceum and Leucojum autumnale $\mathrm{L}$. (Quirion et al., 1991; Kihara et al., 1995; Lewis, 1996). The physical and spectroscopic data of $\mathbf{1}$ coincide with the proposed structure (Fig. 1).

Table I shows the activity of $H$. puniceum extracts (ethanolic and alkaloidal) and compound $\mathbf{1}$ against two insect pests. S. littoralis was sensitive to both extracts and to compound $\mathbf{1}$ while the feeding activity of $L$. decemlineata was not modified by any of the test substances. No toxic (on abdominally injected $L$. decemlineata and orally injected S. littoralis) or mutagenic activity (S. typhimurium) was detected for compound $\mathbf{1}$.

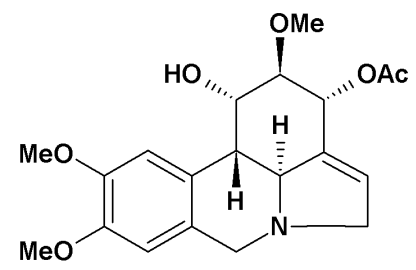

Fig. 1. Chemical structure of 3-O-acetyl-narcissidine (1).

Table I. Feeding reduction of the ethanolic (E) and alkaloidal (A) extracts $\left(100 \mu \mathrm{g} / \mathrm{cm}^{2}\right)$, and compound $\mathbf{1}(50 \mu \mathrm{g} /$ $\mathrm{cm}^{2}$ ) from $H$. puniceum against $L$. decemlineata and $S$. littoralis in choice assays.

\begin{tabular}{|c|c|c|}
\hline \multirow[t]{2}{*}{ Treatment } & \multicolumn{2}{|c|}{ Feeding inhibition $(\% \mathrm{FI})^{\mathrm{a}}$} \\
\hline & L. decemlineata & S. littoralis \\
\hline $\mathrm{E}$ & $<50$ & 69.0 \\
\hline A & $<50$ & 82.7 \\
\hline 1 & 57.0 & 79.1 \\
\hline Eserine $^{c}$ & $\sim 60$ & $>50$ \\
\hline Aconitine $^{c}$ & $>100$ & $32.3(19.6,45.0)^{\mathrm{b}}$ \\
\hline $\begin{array}{l}\text { Methyllyca- } \\
\text { conitine }^{\mathrm{c}}\end{array}$ & $2.8(2.7,2.8)^{\mathrm{b}}$ & $17.7(5.8,53.6)^{\mathrm{b}}$ \\
\hline \multicolumn{3}{|c|}{$\begin{array}{l}\text { a } \% \mathrm{FI}=[1-(\mathrm{T} / \mathrm{C})] \cdot 100 \text {, where } \mathrm{T} \text { and } \mathrm{C} \text { are the } \\
\text { consumption of treated and control leaf disks, respec- } \\
\text { tively. }\end{array}$} \\
\hline \multicolumn{3}{|c|}{$\begin{array}{l}\text { Effective antifeedant dose }\left(\mathrm{EC}_{50}\right) \text { and } 95 \% \text { confidence } \\
\text { (lower, upper })\left(\mu \mathrm{g} / \mathrm{cm}^{2}\right)\end{array}$} \\
\hline
\end{tabular}

Some insecticides, including alkaloids (Miyazawa et al., 1998), are known to inhibit AChE. Amaryllidaceae alkaloids are AChE inhibitors (López et al., 2002; Esameldin et al., 2004; Heinrich and Teoh, 2004; Jin, 2007). In order to establish a comparative model for the insect antifeedant action of 1, we included the antifeedant effects of eserine (physostigmine), aconitine and methyllycaconitine. Eserine is an acetylcholinesterase inhibitor and also inhibits the insect and vertebrate nicotinic cholinergic receptor ( $\mathrm{nAcChR})$. Aconitine is an $\mathrm{Na}^{+}$channel agonist while methyllycaconitine is a competitive antagonist at the muscular and/or insect nAcChR junction (for references see González-Coloma et al., 2004). Compound $\mathbf{1}$ had similar antifeedant and toxic effects to those of methyllycaconitine on S. littoralis (antifeedant without toxicity), suggesting a similar mode of action to this competitive antagonist at the insect $\mathrm{nAcChR}$, in contrast to aconitine which has been reported as being very toxic to both insect species (GonzálezColoma et al., 2004). This is the first report on the antifeedant action of $H$. puniceum extracts and 3-O-acetyl-narcissidine.

Tables II and III summarize the effect of $H$. puniceum extracts and compound $\mathbf{1}$ against several plant species. The root growth of A. hypochondriacus, $R$. cochinchinensis, $P$. maximum (weeds) and $S$. lycopersicum was significantly reduced by $\mathbf{1}$ and both ethanolic and alkaloidal extracts (Table II). The alkaloidal extract and compound $\mathbf{1}$ showed the highest activity against weeds. We also observed abnormal root development in $P$. maximum and $R$. cochinchinensis when treated with 1. P. maximum germination was significantly affected (Table III).

Our results show that $\mathbf{1}$ has strong phytotoxic effects against several plant species. Bi et al. (2003a) described the allelopathic activity of narci-

Table II. Effect of $H$. puniceum extracts $(150 \mu \mathrm{g} /$ plate $)$ and compound 1 (75 $\mu \mathrm{g} / \mathrm{plate})$ on $A$. hypochondriacus (Ah), E. crus-galli (Ec), R. cochinchinensis (Rc), P. maximum $(P m)$ and $S$. lycopersicum $(S l)$ root growth.

\begin{tabular}{lccccc}
\hline Treatment & \multicolumn{5}{c}{ Root growth (\%) } \\
\cline { 2 - 6 } & $A h$ & $E c$ & $R c$ & $P m$ & $S l$ \\
\hline Control & 100 & 100 & 100 & 100 & 100 \\
Ethanolic & $66.2^{*}$ & 98.0 & $43.0^{*}$ & $54.1^{*}$ & $37.5^{*}$ \\
Alkaloidal & $40.0^{*}$ & 72.0 & $37.6^{*}$ & $41.0^{*}$ & $25.4^{*}$ \\
$\mathbf{1}$ & $57.0^{*}$ & 98.6 & $27.2^{*}$ & $48.7^{*}$ & $30.0^{*}$ \\
\hline
\end{tabular}

* Significantly different from the control, $p<0.05$, ANOVA. 
Table III. Effect of $\mathbf{1}$ on the germination and root growth of $R$. cochinchinensis and P. maximum.

\begin{tabular}{lccccc}
\hline Treatment & \multicolumn{2}{c}{$R$. cochinchinensis } & & \multicolumn{2}{c}{$P$ maximum } \\
\cline { 2 - 3 } \cline { 5 - 6 } & Germination (\%) & Abnormal roots (\%) & & Germination (\%) & Abnormal roots (\%) \\
\hline Control & 100.0 & 0.2 & 100.0 & 0.0 \\
$\mathbf{1}$ & 87.5 & $65.0^{*}$ & $52.5^{*}$ & $52.2^{*}$ \\
\hline
\end{tabular}

* Significantly different from the control, $p<0.05$, ANOVA.

clasine (NCS), an Amaryllidaceae alkaloid isolated from Narcissus tazetta bulbs. NCS showed inhibitory effects on seed germination and seedling growth in wheat (Triticum aestivum), and inhibited the chloroplast formation and protein synthesis at the ribosomal level (Bi et al., 2003a; Wouter et al., 2004). The antimitotic activity and inhibitory effect of this alkaloid on isocitrate lyase and hydroxypyruvate reductase has also been reported (Ceriotti, 1967; Bi et al., 2003b; Duke and Dayan, 2006). These enzymes are involved in cotyledon

Anaya A. L., Sims J. J., González-Coloma A., Guadaño A., Hernández-Bautista B. E., Cruz-Ortega R., Midland S. L., Ríos G., Gómez-Pompa A., and Mata R. (2003), Allelochemical potential of Callicarpa acuminata (Verbenaceae). J. Chem. Ecol. 29, 2761-2776.

Asprey G. and Thornton P. (1955), Medicinal plants of Jamaica. W. Indian Med. J. 4, 145-168.

Bi Y. R., Zhang L. X., Guo J. K., Yung K. H., and Wong Y. S. (2003a), Narciclasine alters chloroplast membrane structure and inhibits 5-aminolevulinic acid and chlorophyll binding protein accumulation in wheat (Triticum aestivum) leaves. New Zeal. J. Crop Hort. 31, 335-343.

Bi Y. R., Guo J. K., Zhang L. X., and Wong Y.S. (2003b), Changes in some enzymes of microbodies and plastid development in excised radish cotyledons: Effect of narciclasine. J. Plant Physiol. 160, 10411049.

Ceriotti G. (1967), Narciclasine; an antimitotic substance from Narcissus bulb. Nature 213, 595-596.

Chengwei R. and Bewley D. J. (1999), Developmental and germinative events can occur concurrently in precociously germinating Chinese cabbage (Brassica rapa ssp. Pekinensis) seeds. J. Exp. Bot. 50, 1751-1761.

Citoglu G., Tanker M., and Gumusel B. (1998), Antiinflammatory effects of lycorine and haemanthidine. Phytother. Res. 12, 2005-2006.

Domínguez D. M., Reina M., Santos-Guerra A., Agulló T., López-Balboa C., Santana O., and González-Coloma A. (2008), Pyrrolizidine alkaloids from Canarian endemisms and their antifeedant and phytotoxic effects. Biochem. Syst. Ecol. 36, 153-166.

Duke S. O. and Dayan F. E. (2006), Modes of action of phytotoxins from plants. In: Allelopathy - A Physio- development and are related to the germinative process (McLaughlin and Smith, 1994; Chengwei and Bewley, 1999). Therefore, a similar mode of phytotoxic action could be attributed to $\mathbf{1}$.

In summary, the alkaloid 3- $O$-acetyl-narcissidine (1) from $H$. puniceum acted as an antifeedant against the polyphagous lepidopteran S. littoralis. Additionally this compound also inhibited the root growth, root development and germination of several weeds. The results suggest a plant protection role for $\mathbf{1}$ against some herbivores and plants.

logical Process with Ecological Implications (Reigosa M. J., Pedrol N., and González I., eds.). Springer, Dordrecht, The Netherlands, pp. 511-536.

Esameldin E. E., Stafford G. I., and Johhanes S. (2004), Acetylcholinesterase enzyme inhibitory effects of Amaryllidaceae alkaloids. Planta Med. 70, 260-262.

Fennell C. W. and van Staden J. (2001), Crinum species in traditional and modern medicine. J. Ethnopharmacol. 78, 15-26.

González-Coloma A., Guadaño A., Gutiérrez A., Cabrera R., De La Peña E., De La Fuente G., and Reina M. (1998), Antifeedant Delphinium diterpene alkaloids. Structure-activity relationships. J. Agric. Food Chem. 46, 286-290.

González-Coloma A., Reina M., Guadaño A., Santana O., Gavin J. A., Medinaveitia A., Ruíz-Mesia L., Grandez M., Alva A., and De La Fuente G. (2004), Structural diversity and defensive properties of norditerpenoid alkaloids. J. Chem. Ecol. 30, 1393-1408.

Heinrich M. and Teoh H. L. (2004), Galanthamine from snowdrop - the development of a modern drug against Alzheimer's disease from local Caucasian knowledge. J. Ethnopharmacol. 92, 147-162.

Jin Z. (2005), Amaryllidaceae and Sceletium alkaloids. Nat. Prod. Rep. 22, 111-126.

Jin Z. (2007), Amaryllidaceae and Sceletium alkaloids. Nat. Prod. Rep. 24, 886-905.

Kihara M., Ozaki T., Kobayashi S., and Shingu T. (1995), Alkaloidal constituents of Leucojum autumnale L. (Amaryllidaceae). Chem. Pharm. Bull. 43, 318-320.

Lewis J. R. (1996), Amaryllidaceae alkaloids. Nat. Prod. Rep. 13, 303-308.

Liu J., Hu W. X., He L. F., Ye M., and Li Y. (2004), Effects of lycorine on HL-60 cells via arresting cell cycle and inducing apoptosis. FEBS Lett. 578, 245-250. 
López S., Bastida J., Viladomant F., and Codina C. (2002), Acetylcholinesterase inhibitory activity of some Amaryllidaceae alkaloids and Narcissus extracts. Life Sci. 71, 2521-2529.

McLaughlin J. C. and Smith S. M. (1994), Metabolic regulation of glyoxylate-cycle enzyme synthesis in detached cucumber cotyledons and protoplast. Planta 195, 1432-2048.

Meerow A. W. (1990), Amaryllidaceae. In: Flora of Ecuador (Harling G. and Andersson L., eds.). Univ. Goteborg/Riksmuseum, Stockholm/Pontificia, Univ. Católica del Ecuador, Quito, Vol. 41, pp. 1-52.

Mitchell S. A. and Ahmad M. H. (2006), A review of medicinal plant research at the University of the West Indies. W. Indian Med. J. 55, 243-269.

Miyazawa M., Yoshio K., Ishikawa Y., and Kameoka H. (1998), Insecticidal alkaloids against Drosophila melanogaster from Nuphas japonicum DC. J. Agric. Food Chem. 46, 1059-1063.

Pettit G. R., Gaddamidi V., Herald D. L., Singh S. B., Cragg G. M., Schmidt J. M., Boettner F. E., Williams M., and Sagawa Y. (1986), Antineoplastic agents 120. Pancratium littorale. J. Nat. Prod. 49, 995-1002.

Poitout S. and Bues S. (1970), Elevage de plusieurs especes de Lepidopteres Noctuidae sur milieu artificiel simplifié. Ann. Zool. Ecol. Anim. 2, 79-91.
Polt R. (1996), Amaryllidaceae alkaloids with antitumor activity. Org. Synth. 3, 109-148.

Quirion J. C., Husson H. P., Weniger B., Jimenez F., and Zanoni T. A. (1991), (-)-3-O-Acetylnarcissidine, a new alkaloid from Hippeastrum puniceum. J. Nat. Prod. 54, 1112-1114.

Reina M., González-Coloma A., Gutiérrez C., Cabrera R., Rodríguez M., Villaroel L., and Fajardo V. (2001), A defensive chemistry of Senecio miser Hook. J. Nat. Prod. 64, 6-11.

Sener B., Orhan I., and Satayavivad J. (2003), Antimalarial activity screening of some alkaloids and the plant extracts from Amaryllidaceae. Phytother. Res. 17, 1220-1223.

Szlávik L., Gyuris A., Minárovits J., Forgo P., Molnár J., and Hohmann J. (2004), Alkaloids from Leucojum vernum and antiretroviral activity of Amaryllidaceae alkaloids. Planta Med. 70, 871-873.

Unver N. (2007), New skeletons and new concepts in Amaryllidaceae alkaloids. Phytochem. Rev. 6, 125135.

Weniger B., Italiano L., Beck J. P., Bastida J., Bergonon S., Codina C., Lobstein A., and Anton R. (1995), Cytotoxic activity of Amaryllidaceae alkaloids. Planta Med. 61, 77-79.

Wouter G., Sinz A., and Tommassen M. M. (2004), Daffodil flowers delay senescence in cut Iris flowers. Phytochemistry $\mathbf{6 5}, 571-577$. 